\title{
PENGARUH KOMPETENSI, DISIPLIN KERJA, SIKAP MENTAL DAN MOTIVASI \\ KERJA TERHADAP KINERJA PEGAWAI DI BADAN KEPEGAWAIAAN DAN PENGEMBANGAN SUMBER DAYA MANUSIA KABUPATEN BARITO SELATAN
}

\author{
Abdul Azis Norwijaya, Nurus Sjamsi, M. Zaid Abdurrakhman \\ Sekolah Tinggi Ilmu Ekonomi Pancasetia Banjarmasin \\ Jl. Ahmad Yani Km. 5.5 Banjarmasin \\ azisadoel76@gmail.com
}

\begin{abstract}
This research is aimed to determine and analyze the influence simultaneous and partially of competency, work discipline, mental attitude and, work motivation on employee performance and to determine the dominant factor influencing the employee performance in Employee and Human Resources Development Department of South Barito. Respondents in this research are employees who work at Employee and Human Resources Development Department of South Barito using saturated sample technique consists of 41 people. Instrument of this research using data collection method by questionnaire which were analyzed by validity and realibility test. Research data was analyzed by stastical multiple linear regressions model using SPSS version 23. The result of this research proved that competency, work discipline, mental attitude and, work motivation have significant simultaneous influence on employee performance. Partially, competency, work discipline, mental attitude and work motivation have significant simultaneous influence on employee performance. In addition, competency has most dominant influence to increase employee performance in Employee and Human Resources Development Department of South Barito.
\end{abstract}

Keywords : Competency, Work Discipline, Mental Attitude, Work Motivation and Employee Performance.

Abstrak: Penelitian ini bertujuan untuk mengetahui dan menganalisis pengaruh Kompetensi, Disiplin Kerja, Sikap Mental dan Motivasi kerja secara simultan dan secara parsial serta variabel yang berpengaruh dominan terhadap kinerja pegawai di Badan Kepegawaian dan Pengembangan Sumber Daya Manusia Kabupaten Barito Selatan. Responden penelitian ini adalah pegawai Badan Kepegawaian dan Pengembangan Sumber Daya Manusia berjumlah 41 dengan teknik sampling jenuh, Instrumen penelitian adalah kuesioner dan dilakukan uji validitas dan reliabilitas. Data diuji dengan analisis regresi linear berganda menggunakan aplikasi SPSS versi 23. Hasil penelitian menemukan bahwa : Kompetensi, Disiplin Kerja, Sikap Mental dan Motivasi kerja secara simultan berpengaruh terhadap Kinerja pegawai. Kompetensi, Disiplin Kerja, Sikap Mental dan Motivasi kerja secara parsial berpengaruh terhadap Kinerja pegawai dan Kompentensi yang berpengaruh Dominan terhadap Kinerja pegawai, di Badan Kepegawaian dan Pengembangan Sumber Daya Manusia Kabupaten Barito Selatan.

Kata-kata kunci : Kompetensi, Disiplin Kerja, Sikap Mental, Motivasi, Kinerja Pegawai 
PENDAHULUAN

\subsection{Latar Belakang Masalah}

Badan Kepegawaian dan Pengem bangan Sumber Daya Manusia (BKPSDM) adalah bagian dari struktur pemerintahan Kabupaten Barito Selatan yang bertugas dan bertanggung jawab terhadap ketertiban dan kelancaran administrasi kepegawaian seluruh pegawai yang aktif bertugas di Kabupaten Barito Selatan. Perfomance atau kinerja BKPSDM terletak pada kualitas tersedianya Sumber Daya Manusia yang aktif bertugas di masing-masing bidangnya.

Bagaimanapun canggihnya suatu tehnologi yang tersedia dalam menunjang kerja apabila tidak diikuti tenaga personil yang berkualitas untuk mengelola kegiatan dan aktivitas tugas yang berkaitan dengan pemerintahan, akan terjadi ketimpangan, keterlambatan dalam memberikan pelayanan kepada pihak internal maupun eksternal, karena kinerja pemerintahan Kabupaten Barito Selatan terutama peran BKPSDM sebagai unit yang paling bertanggung jawab sangat dipengaruhi dan bahkan tergantung pada kualitas dan kemampuan kompetitif sumber daya manusia yang dimilikinya.

Kinerja pegawai akan menjadi baik apabila kompetensi yang dimiliki para pegawai juga baik khususnya yang bertugas di BKPSDM masih diperlukan adanya peningkatan dan pembekalan melalui pendidikan dan pelatihan yang berkesinambungan agar kompetensi yang dimiliki dapat menyesuaikan dengan keadaan yang selalu berubah tiada henti, dari segi bisnis, system pemerintahan, keinginan masyarakat sebagai stake holder dan para pihak yang berkepentingan lainnya. Sesuai dengan pendapat dari Boulter, Dalziel, Hall (2003) dalam Sutrisno (2009) menyatakan bahwa kompetensi adalah suatu karakteristik dasar dari seseorang yang memungkinkannya memberikan kinerja unggul dalam pekerjaan, peran atau situasi tertentu Hasil penelitian Bontis, Dragonetti, Jacobson and Roos (1993) menjelaskan bahwa kompetensi yang diperoleh dari hasil pendidikan dan pelatihan dapat mempengaruhi kinerja pegawai karena pegawai telah memiliki pengetahuan dan ketrampilan yang cukup dalam melaksanakan seluruh tugas yang dibebankan kepadanya serta perilaku kerja yang baik.

Berdasarkan data pegawai tahun 2020 dari tingkat pendidikan yang dimiliki para pegawai dari berbagai disiplin ilmu dan jurusan serta jenjang pendidikan yang merupakan dasar kompetensi para pegawai dihubungkan dengan tugas dan pekerjaan yang menjadi tanggungjawabnya, terdapat perbedaan yang signifikan antara kompetensi dengan pekerjaan atau tupoksinya. Jumlah pegawai sebanyak 41 pegawai, sedangkan yang memiliki pendidikan sesuai dengan tupoksinya sebanyak 18 pegawai atau 44\%, pegawai yang kurang sesuai dengan tupoksinya 11 pegawai atau $27 \%$ dan yang tidak sesuai sebanyak 12 pegawai atau 29\%. Komposisi seperti ini menyebabkan tugasnya dapat diselesaikan tetapi tidak sesuai dengan standar yang telah ditetapkan. Apabila kondisi ini tidak segera diadakan perbaikan dan perubahan maka kinerja pegawai yang tidak mempunyai basis kompetensi yang tidak sesuai dengan tugasnya akan mempengaruhi kinerja yang dicapainya, bahkan pegawai yang sesuai dengan kompetensinya masih juga mengalami kinerja yang tidak sesuai dengan ketentuan yang ditetapkan.

Permasalahan yang dihadapi sekarang adalah "bagaimana cara agar sumber daya manusia yang tersedia menjadi berkualitas dan faktor-faktor apa saja yang mempengaruhi kualitas sumber daya manusia". Diawali dengan kompetensi yang dimiliki pegawai saat ini yang meliputi pengetahuan, ketampilan dan 
kemampuan atau kapabilitas yang dimiliki personil pegawai selalu ditinjau ulang untuk menyesuaikan dengan program yang akan dicapai oleh BKPSDM termasuk memberikan pelatihan yang bertujuan meningkatkan ketrampilan teknis berkaitan dengan tugas kesehariannya serta menyesuaikan sikap mental cara bekerja yang menjadi bagian dari dirinya sehingga mewarnai perilaku kognitif, efektif dan psikomotoriknya. Finch dan Crunkilton dalam Muliyasa (2004) mengatakan, bahwa kompetensi merupakan penguasaan terhadap suatu tugas, ketrampilan, sikap, apresiasi yang harus dimiliki pegawai dalam melaksanakan tugasnya. Dengan demikian maka suatu kompetensi harus didukung oleh pengetahuan, sikap mental dan perilaku yang dapat membentuk pegawai menjadi sesuai dengan yang diharapakan oleh organisasi pemerintahan yang ekselen, karena tanpa pengetahuan dan ketrampilan serta sikap mental yang baik tidak mungkin muncul suatu kompetensi yang berdampak pada kinerja pemerintahan di Kabupaten Barito Selatan.

Unsur disiplin kerja juga diperlukan dalam menunjang prestasi kerja karena disiplin kerja adalah sikap, tingkah laku dan perbuatan yang sesuai dengan peraturan yang telah ditetapkan oleh pemerintahan Kabupaten Barito Selatan, secara tertulis maupun tidak tertulis. Tujuan utama disiplin kerja adalah untuk meningkatkan kinerja sehingga peningkatan disiplin kerja adalah suatu upaya untuk membina para pegawai sekaligus sebagai hukuman apabila pegawai tidak mematuhinya. Tindakan disiplin merupakan langkah terakhir yang bisa dilakukan terhadap seorang pegawai yang kinerjanya di bawah standard. Tindakan disiplin dapat berupa teguran tertulis (reprimends), pensekoran (suspension), penurunan pangkat atau gaji (reduction is rank of pay) dan pemecatan (tiring). Tindakan disiplin ini dilakukan karena adanya kejadian perilaku khusus dari pegawai yang menyebabkan rendahnya kinerja atau pelanggaran-aturan-aturan yang ada dalam pemerintahan. Sebaliknya bagi pegawai yang memiliki disiplin yang tinggi dalam melaksanakan tugasnya, akan mendapatkan reward karena mampu menunjukkan kinerja yang superior.

Motivasi bagi pegawai dapat memberikan dorongan untuk berkinerja yang baik dalam sepanjang kariernya, maka pemberian motivasi terhadap pegawai sangat penting untuk dilakukan secara berkelanjutan bagi atasan tentang atau pimpinan bagaimana cara dalam memberikan motivasi agar pegawai dapat terdorong dalam melaksanakan pekerjaannya dengan semangat kerja yang tinggi. Apabila dalam pemberian motivasi kepada karyawan kurang efektif, maka hal tersebut akan berdampak langsung terhadap kinerja karyawan meskipun pegawai memiliki kemampuan yang baik tanpa pemberian motivasi tidak akan mencapai kinerja yang dapat diharapkan.

Berdasarkan uraian latar belakang masalah seperti diutarakan di atas, penulis ingin melakukan penelitian tentang : Pengaruh Kompetensi, Disiplin Kerja, Sikap Mental dan Motivasi Terhadap Kinerja pegawai di Badan Kepegawaian dan Pengembangan Sumber Daya Manusia Kabupaten Barito Selatan.

\subsection{Rumusan Masalah}

a. Apakah kompetensi, disiplin kerja, sikap mental dan motivasi kerja berpengaruh signifikan secara simultan terhadap kinerja pegawai di Badan Kepegawaiaan dan Pengembangan Sumber Daya Manusia Kabupaten Barito Selatan?

b. Apakah kompetensi, disiplin kerja, sikap mental dan motivasi kerja berpengaruh signifikan secara 
parsial terhadap kinerja pegawai di Badan Kepegawaiaan dan Pengembangan Sumber Daya Manusia Kabupaten Barito Selatan?

c. Manakah diantara kompetensi, disiplin kerja, sikap mental dan motivasi kerja yang berpengaruh dominan terhadap kinerja pegawai di Badan Kepegawaiaan dan Pengembangan Sumber Daya Manusia Kabupaten Barito Selatan?

\subsection{Tujuan Penelitian}

a. Untuk mengetahui dan menganalisis pengaruh kompe tensi, disiplin kerja, sikap mental dan motivasi kerja secara simultan terhadap kinerja pegawai Pengembangan Sumber Daya Manusia Kabupaten Barito Selatan.

b. Untuk mengetahui dan menganalisis pengaruh kompe tensi, disiplin kerja, sikap mental dan motivasi kerja secara parsial terhadap kinerja pegawai Pengembangan Sumber Daya Manusia Kabupaten Barito Selatan.

c. Untuk mengetahui dan menganalisis manakah diantara kompetensi, disiplin kerja, sikap mental dan motivasi kerja yang berpengaruh dominan terhadap kinerja pegawai di Badan Kepegawaiaan dan Pengembangan Sumber Daya Manusia Kabupaten Barito Selatan.

\section{TINJAUAN PUSTAKA}

\subsubsection{Kompetensi}

Kompetensi itu adalah suatu pengetahuan, ketrampilan dan kemampuan atau kapabilitas yang dimiliki oleh seseorang yang telah menjadi bagian dari dirinya sehingga mewarnai perilaku kognitif, afektif dan psikomotoriknya. Boulter, Dalziel, Hall (2003) dalam Sutrisno (2009) menyatakan bahwa kompetensi adalah suatu karakteristik dasar dari seseorang yang memungkinkannya memberikan kinerja unggul dalam pekerjaan, peran atau situasi tertentu. Ketrampilan adalah hal-hal yang bisa dilakukan seseorang dengan baik. Pengetahuan adalah apa yang diketahui sesorang tentang suatu topik. Peran sosial adalah citra yang ditunjukkan oleh seseorang. Berdasarkan pendapat di atas, maka suatu kompetensi harus didukung oleh pengetahuan, sikap dan apresiasi. Finch dan Crunkilton dalam Mulyasa (2004), mengertikan kompetensi sebagai penguasaan terhadap suatu tugas, ketrampilan, sikap dan apresiasi yang diperlukan untuk menunjang keberhasilan. Hal ini menggambarkan bahwa kompetensi mencakup tugas, keterampilan, sikap dan apresiasi yang diperlukan untuk menunjang peningkatan kinerja.

Kompetensi merupakan aspek-aspek pribadi dari seorang pegawai yang memungkinkan orang tersebut mencapai kinerja yang superior. Menurut Spenser \& Spenser (1993) kompetensi merupakan karakteristik individu yang mendasari diri seseorang dan menyebabkan sanggup menunjukkan kinerja atau produktivitas kerja yang efektif atau superior di dalam suatu pekerjaan. Karakteristik dimaksud adalah. Pertama; karakteristik dasar. Yang dimaksud dengan karakteristik dasar di sini adalah mencakup kepribadian seseorang dan dapat memprediksikan sikap seseorang pada situasi tertentu yang bervariasi pada aktivitas pekerjaan tertentu. Kedua; hubungan kausal berarti kompetensi dapat menyebabkan atau digunakan untuk memprediksi performansi (kinerja) seseorang. Ketiga; kriteria yang dijadikan acuan kompetensi secara nyata akan mempredikasikan seseorang dapat bekerja lebih baik atau buruk, sebagaimana terukur 
pada kriteria spesifik atau sesuai standar pekerjaan.

\subsubsection{Disiplin Kerja}

Nitisemo (1996;12) memberikan suatu penjelasan tentang pengertian dan kedisiplinan tersebut, seperti dikutip ini : Kedisiplinan lebih tepat kalau diartikan sebagai suatu sikap, tingkah laku dan perbuatan yang sesuai dengan peraturan perusahaan baik yang tertulis maupun tidak tertulis ". Sedangkan pendapat yang lebih spesifik diungkapakan oleh Siswanto (1989 : 278) yaitu : "Disiplin kerja dapat didefinisikan sebagi suatu sikap patuh, menghormati dan taat terhadap peraturan-peraturan yang berlaku baik yang tertulis maupun tidak tertulis serta sanggup menjalankannya dan tidak mengelak untuk menerima sangsi-sangsi apabila ia melanggar tugas dan wewenang yang diberikan kepadanya". Pendapat lain dari Hasibuan (1994 : 212) mengemukakan bahwa : "Disiplin kerja adalah kesadaran dan kesediaan seseorang mentaati semua peraturan perusahaan dan normanorma sosial yang berlaku". Jadi pada intinya disiplin kerja menghendaki suatu sikap yang harus dimiliki oleh karyawan untuk mematuhi, menghormati, dan mentaati semua peraturan baik itu peraturan tertulis yang berupa norma-norma maupun peraturanperaturan yang tidak tertulis yang dianut oleh perusahaan tersebut. Menegakkan disiplin kerja penting sekali bagi perusahaan sebab dengan kedisiplinan itu diharapkan sebagian peraturan dapat ditaati oleh setiap karyawan. Perlu sekali digaris bawahi sebagian besar dalam kenyataanya sulit sekali peraturan perusahaan tersebut bisa dipatuhi keseluruhannya oleh setiap karyawan.

\subsubsection{Sikap Mental}

Gibson (1997) dalam umum (2018) menjelaskan sikap mental sebagai perasaan positif atau negative atau keadaan mental yang selalu disiapkan, dipelajari dan diatur melalui pengalaman yang memberikan pengaruh khusus pada respons seseorang terhadap orang, obyek ataupun keadaan. Sikap adalah kesiapan bagi seseorang untuk bertindak dengan cara tertentu. Sikap adalah suatu hasil proses dan pikiran mengenai objek tertentu setelah dirangsang baik dari dalam maupun dari luar. Dapat diketahui bahwa sikap adalah suatu pandangan atau ketetapan hati seseorang terhadap objek yang akan diikuti dengan perbuatan setelah ada rangsangan untuk berbuat. Dalam suatu organisasi sikap mental yang ditujukan oleh pegawai terhadap pekerjaannya sangat penting artinya karena menjadi salah satu faktor keberhasilan organisasi tersebut.

\subsubsection{Motivasi}

Malayu S.P. Hasibuan (2001) menyatakan motivasi adalah pemberian daya penggerak yang menciptakan kegairahan kerja seseorang agar mereka mau bekerja sama, bekerja efektif dan terintegrasi dengan segala daya upayanya untuk mencapai kepuasan. Menurut A. Manullang dan Marihot Manulang (2004) dengan mengutip pendapat The Liang Gie menyatakan bahwa perumusan motivating atau pendorong kegiatan sebagai berikut "Pekerjaan yang dilakukan oleh seorang manajer dalam memberikan inspirasi, semangat dan dorongan kepada orang lain, dalam hal ini karyawannya untuk mengambil tindakan-tindakan.

\section{HIPOTESIS}

1. Kompetensi, disiplin kerja, sikap mental dan motivasi kerja secara simultan berpengaruh terhadap kinerja pegawai di Badan Kepegawaiaan dan 
Pengembangan Sumber Daya Manusia Kabupaten Barito Selatan.

2. Kompetensi, disiplin kerja, sikap mental dan motivasi kerja secara parsial berpengaruh terhadap kinerja pegawai di Badan Kepegawaiaan dan Pengembangan Sumber Daya Manusia Kabupaten Barito Selatan.

3. Kompetensi berpengaruh dominan terhadap kinerja pegawai di Badan Kepegawaiaan dan Pengembangan Sumber Daya Manusia Kabupaten Barito Selatan.

\section{METODE PENELITIAN}

\subsection{Jenis penelitian}

Metode penelitian yang akan digunakan dalam penelitian ini adalah metode kuantitatif dengan pendekatan penelitian deskriptif dan analisis verifikatif karena adanya variabelvariabel yang akan ditelaah hubungannya serta tujuannya untuk menyajikan gambaran secara terstruktur, faktual, mengenai faktafakta hubungannya antara variabel yang diteliti.

\subsection{Variabel Penelitian}

Variabel independen adalah kinerja pegawai sedangkan variabel dependen terdiri dari kompentensi, disiplin kerja, sikap mental dan motivasi.

\subsection{Populasi dan Sampel}

Populasi dalam penelitian ini adalah para pegawai di Badan Kepegawaiaan dan Pengembangan Sumber Daya Manusia. Penentuan ukuran sampel responden menggunakan sampel jenuh sebanyak 41 orang.

\subsection{Teknik Analisa Data}

Pengumpulan data dilakukan dengan cara menyebarkan kuisioner, survey lapangan, studi kepustakaan dan observasi. Teknik analisa data menggunakan analisa deskriptif dan analisa regresi linier berganda dengan bantuan aplikasi SPSS versi 23.

\subsection{Lokasi Penelitian}

Lokasi penelitian adalah Badan Kepegawaiaan dan Pengembangan Sumber Daya Manusia Kabupaten Barito Selatan di Jalan Bandara
Sanggu, Buntok Kabupaten Barito Selatan Provinsi Kalimantan Tengah.

ANALISIS HASIL PENELITIAN DAN PEMBAHASAN

1. Karakteristik Responden Berdasarkan Jenis Kelamin

\begin{tabular}{|l|c|c|}
\hline \multicolumn{1}{|c|}{ Jenis Kelamin } & Jumlah & \% \\
\hline (1) & $(\mathbf{2})$ & $\mathbf{( 3 )}$ \\
\hline Laki-laki & 27 & 65.85 \\
\hline Perempuan & 14 & 34.15 \\
\hline Total & $\mathbf{4 1}$ & $\mathbf{1 0 0}$ \\
\hline
\end{tabular}

2. Karakteristik Responden Berdasarkan Umur

\begin{tabular}{|c|c|c|}
\hline \multirow{2}{*}{ Umur } & \multicolumn{2}{c|}{ Frekuensi } \\
\cline { 2 - 3 }$(\mathbf{1})$ & Jumlah & \% \\
\hline $24-30$ & $\mathbf{( 2 )}$ & $\mathbf{( 3 )}$ \\
\hline $31-37$ & 4 & 9.76 \\
\hline $38-44$ & 11 & 26.83 \\
\hline $45-56$ & 19 & 46.34 \\
\hline Total & 7 & 17.07 \\
\hline
\end{tabular}

3. Karakteristik Responden berdasarkan Tingkat Pendidikan

\begin{tabular}{|l|c|c|}
\hline \multirow{2}{*}{$\begin{array}{c}\text { Tingkat } \\
\text { Pendidikan }\end{array}$} & \multicolumn{2}{|c|}{ Frekuensi } \\
\cline { 2 - 3 }$(\mathbf{1})$ & Jumlah & \% \\
\hline SLTA & $(\mathbf{2})$ & $\mathbf{( 3 )}$ \\
\hline D3 & 6 & 14.63 \\
\hline S1 & 14 & 34.15 \\
\hline S2 & 17 & 41.46 \\
\hline Total & 4 & 9.76 \\
\hline
\end{tabular}

\section{Karakteristik Responden} Berdasarkan Masa Kerja

\begin{tabular}{|l|c|c|}
\hline \multirow{2}{*}{ Masa Kerja (Th) } & \multicolumn{2}{|c|}{ Frekuensi } \\
\cline { 2 - 3 } & Jumlah & \% \\
\hline (1) & $\mathbf{( 2 )}$ & $\mathbf{( 3 )}$ \\
\hline $5-10$ & 7 & 17.07 \\
\hline $11-15$ & 11 & 26.83 \\
\hline $16-20$ & 19 & 46.34 \\
\hline $21-25$ & 4 & 9.76 \\
\hline Total & $\mathbf{4 1}$ & $\mathbf{1 0 0}$ \\
\hline
\end{tabular}

Analisis Hasil Penelitian

a. Hasil Uji Validitas dan Reliabilitas

\begin{tabular}{|c|c|c|c|}
\hline $\begin{array}{c}\text { Indikator/ } \\
\text { item }\end{array}$ & R Hitung & $\begin{array}{c}\text { Kriteria } \\
\text { R Tabel }\end{array}$ & Ket \\
\hline X1.1.1 & 0.715 & & Valid \\
\hline X1.1.2 & 0.457 & \multirow{4}{*}{$>0.3081$} & Valid \\
\hline X1.2.1 & 0.721 & & Valid \\
\hline X1.2.2 & 0.654 & & Valid \\
\hline
\end{tabular}




\begin{tabular}{|c|c|c|c|}
\hline $\begin{array}{c}\text { Indikator/ } \\
\text { item }\end{array}$ & R Hitung & $\begin{array}{l}\text { Kriteria } \\
\text { R Tabel } \\
\end{array}$ & Ket \\
\hline X1.3.1 & 0.651 & \multirow{8}{*}{$>0.3081$} & Valid \\
\hline X1.3.2 & 0.609 & & Valid \\
\hline X1.4.1 & 0.627 & & Valid \\
\hline X1.4.2 & 0.533 & & Valid \\
\hline X1.5.1 & 0.491 & & Valid \\
\hline X1.5.2 & 0.599 & & Valid \\
\hline X1.6.1 & 0.540 & & Valid \\
\hline X1.6.2 & 0.621 & & Valid \\
\hline X2.1.1 & 0.666 & \multirow{5}{*}{$>0.3081$} & Valid \\
\hline X2.1.2 & 0.766 & & Valid \\
\hline X2.2.1 & 0.738 & & Valid \\
\hline X2.2.2 & 0.698 & & Valid \\
\hline X2.3.1 & 0.693 & & Valid \\
\hline X3.1.1 & 0.590 & \multirow{8}{*}{$>0.3081$} & Valid \\
\hline X3.1.2 & 0.690 & & Valid \\
\hline X3.2.1 & 0.728 & & Valid \\
\hline X3.2.2 & 0.664 & & Valid \\
\hline X3.3.1 & 0.656 & & Valid \\
\hline X3.3.2 & 0.556 & & Valid \\
\hline X3.4.1 & 0.438 & & Valid \\
\hline X3.4.2 & 0.392 & & Valid \\
\hline X4.1.1 & 0.487 & \multirow{12}{*}{$>0.3081$} & Valid \\
\hline X4.1.2 & 0.545 & & Valid \\
\hline X4.2.1 & 0.709 & & Valid \\
\hline $\mathrm{X} 4.2 .2$ & 0.629 & & Valid \\
\hline X4.3.1 & 0.581 & & Valid \\
\hline $\mathrm{X} 4.3 .2$ & 0.505 & & Valid \\
\hline X4.4.1 & 0.530 & & Valid \\
\hline $\mathrm{X} 4.4 .2$ & 0.452 & & Valid \\
\hline $\mathrm{X} 4.5 .1$ & 0.337 & & Valid \\
\hline $\mathrm{X} 4.5 .2$ & 0.479 & & Valid \\
\hline X4.6.1 & 0.346 & & Valid \\
\hline X4.6.2 & 0.437 & & Valid \\
\hline Y1.1 & 0.643 & \multirow{7}{*}{$>0.3081$} & Valid \\
\hline Y1.2 & 0.677 & & Valid \\
\hline Y1.3 & 0.701 & & Valid \\
\hline Y1.4 & 0.670 & & Valid \\
\hline Y1.5 & 0.647 & & Valid \\
\hline Y1.6 & 0.462 & & Valid \\
\hline Y1.7 & 0.565 & & Valid \\
\hline
\end{tabular}

\begin{tabular}{|l|c|c|c|}
\hline \multicolumn{1}{|c|}{ Variabel } & $\begin{array}{c}\text { Cronbach's } \\
\text { Alpha }\end{array}$ & Cut Value & $\begin{array}{c}\text { Hasil } \\
\text { Pengujian }\end{array}$ \\
\hline \multicolumn{1}{|c|}{$(1)$} & $(2)$ & $(3)$ & $(4)$ \\
\hline Kompetensi & 0.8 & 0.6 & Reliabel \\
\hline Disiplin Kerja & 0.7 & 0.6 & Reliabel \\
\hline Sikap Mental & 0.7 & 0.6 & Reliabel \\
\hline Motivasi & 0.7 & 0.6 & Reliabel \\
\hline Kinerja & 0.7 & 0.6 & Reliabel \\
\hline
\end{tabular}

\section{b. Hasil Analisa Regresi Linier Berganda}

\begin{tabular}{|l|c|c|c|c|c|}
\hline \multirow{2}{*}{\multicolumn{1}{|c|}{ Model }} & \multicolumn{2}{|c|}{$\begin{array}{c}\text { Unstandardized } \\
\text { Coefficients }\end{array}$} & $\begin{array}{c}\text { Standardized } \\
\text { Coefficients }\end{array}$ & & \\
\cline { 2 - 5 } & $\mathrm{B}$ & $\begin{array}{c}\text { Std. } \\
\text { Error }\end{array}$ & Beta & $\mathrm{t}$ & \multirow{2}{*}{ Sig. } \\
\hline (Constant) & -2.593 & 1.764 & & -1.470 & .150 \\
\hline Kompetensi & .173 & .054 & 298 & 3.212 & .003 \\
\hline Disiplin Kerja & .287 & .139 & .228 & 2.068 & .046 \\
\hline Sikap Mental & .263 & .112 & .265 & 2.342 & .025 \\
\hline Motivasi & .171 & .077 & .243 & 2.230 & .032 \\
\hline
\end{tabular}

Berdasarkan hasil analisis regresi pada tabel diatas, diperoleh nilai kontanta regresi sebesar -2,593 dengan koefisien regresi variabel kompetensi sebesar 0,173, koefisien regresi variabel disiplin kerja sebesar 0,287, koefisien regresi variabel sikap mental sebesar 0,263 dan koefisien regresi variabel motivasi sebesar 0,171, sehingga diperoleh persamaan regresi sebagai berikut :

$$
\begin{gathered}
Y=-0,2593+0,173 X_{1}+0,287 X_{2}+ \\
0,3263 X_{3}+0.171 X_{4}
\end{gathered}
$$

Keterangan :

$\mathrm{Y}=$ Kinerja Pegawai $(\mathrm{Y})$

$\mathrm{X}_{1}=$ Kompetensi $\left(\mathrm{X}_{1}\right)$

$\mathrm{X}_{2}=$ Disiplin Kerja $\left(\mathrm{X}_{2}\right)$

$\mathrm{X}_{3}=$ Sikap Mental $\left(\mathrm{X}_{3}\right)$

$\mathrm{X}_{4}=\operatorname{Motivasi}\left(\mathrm{X}_{4}\right)$

\begin{tabular}{|c|c|c|c|}
\hline No & Uraian Hipotesis & Sig. & Keputusan \\
\hline (1) & (2) & (3) & (4) \\
\hline 1 & $\begin{array}{l}\text { Kompetensi, disiplin } \\
\text { kerja, sikap mental } \\
\text { dan motivasi kerja } \\
\text { secara simultan } \\
\text { berpengaruh } \\
\text { terhadap kinerja } \\
\text { pegawai di Badan } \\
\text { Kepegawaiaan dan } \\
\text { Pengembangan } \\
\text { Sumber Daya } \\
\text { Manusia Kabupaten } \\
\text { Barito Selatan. }\end{array}$ & $\begin{array}{l}\text { - } \text { Sig. }= \\
0,000 \\
0,050 \\
\text { - F hitung } \\
=85,86>\mathrm{F} \\
\text { tabel }=2,63\end{array}$ & $\begin{array}{c}\text { Hipotesis } 1 \\
\text { diterima }\end{array}$ \\
\hline
\end{tabular}

\section{Hasil Uji Hipotesis}




\begin{tabular}{|c|c|c|c|}
\hline No & Uraian Hipotesis & Sig. & Keputusan \\
\hline (1) & (2) & (3) & (4) \\
\hline 2 & $\begin{array}{l}\text { Kompetensi, disiplin } \\
\text { kerja, sikap mental } \\
\text { dan motivasi kerja } \\
\text { secara parsial } \\
\text { berpengaruh } \\
\text { terhadap kinerja } \\
\text { pegawai di Badan } \\
\text { Kepegawaiaan dan } \\
\text { Pengembangan } \\
\text { Sumber Daya } \\
\text { Manusia Kabupaten } \\
\text { Barito Selatan. }\end{array}$ & \begin{tabular}{|l} 
T hitung $\mathrm{X}_{1}$ \\
$=3,212>\mathrm{T}$ \\
Tabel = \\
2,028 \\
dengan Sig \\
$\mathrm{X}_{1}=0,000$ \\
$<0,050$ \\
- T hitung $\mathrm{X}_{2}$ \\
$=2,068>\mathrm{T}$ \\
Tabel = \\
2,028 \\
dengan Sig \\
$\mathrm{X} 1=0,046$ \\
$<0,050$ \\
T hitung $\mathrm{X}_{3}$ \\
$=2,342>\mathrm{T}$ \\
Tabel = \\
2,028 \\
dengan Sig \\
$\mathrm{X} 1=0,025$ \\
$<0,050$ \\
- T hitung $\mathrm{X}_{4}$ \\
$=2,230>\mathrm{T}$ \\
Tabel = \\
2,028 \\
dengan Sig \\
$\mathrm{X} 1=0,032$ \\
$<0,050$
\end{tabular} & $\begin{array}{c}\text { Hipotesis } 2 \\
\text { diterima }\end{array}$ \\
\hline 3 & $\begin{array}{l}\text { Kompetensi } \\
\text { berpengaruh } \\
\text { dominan terhadap } \\
\text { kinerja pegawai di } \\
\text { Badan } \\
\text { Kepegawaiaan dan } \\
\text { Pengembangan } \\
\text { Sumber Daya } \\
\text { Manusia Kabupaten } \\
\text { Barito Selatan. }\end{array}$ & \begin{tabular}{|l} 
- Koefisien Beta \\
$\mathrm{X}_{1}=0,298$ \\
- Koefisien Beta \\
$\mathrm{X}_{2}=0,228$ \\
- Koefisien Beta \\
$\mathrm{X}_{3}=0,265$ \\
- Koefisien Beta \\
$\mathrm{X}_{4}=0,243$ \\
\\
Paling besar $=\mathrm{X}_{1}$ \\
(Kompetensi)
\end{tabular} & $\begin{array}{c}\text { Hipotesis } 3 \\
\text { diterima }\end{array}$ \\
\hline
\end{tabular}

\section{Pembahasan Hasil Penelitian}

1. Pengaruh simultan kompetensi, disiplin kerja, sikap mental dan motivasi terhadap kinerja pegawai.

Berdasarkan hasil uji sig dan nilai $\mathrm{F}$ dalam penelitian ini maka hipotesis 1 terbukti dan disimpulkan bahwa secara simultan kompetensi, disiplin kerja, sikap mental dan motivasi kerja berpengaruh signifikan terhadap kinerja pegawai.

Para pegawai Badan Kepegawaian dan Pengembangan Sumber Daya Manusia Kabupaten Barito Selatan merasakan ada perasaan positif untuk meningkatkan kinerja apabila kompetensi kerja yang mereka miliki didukung oleh pimpinan dengan cara meningkatkan kemampuan yang mereka miliki baik melalui peningkatan pendidikan maupun pelatihan. Tidak hanya itu, dengan adanya peraturan yang diterapkan oleh organisasi sehingga para pegawai merasakan pengaruh dari keselarasan aturan yang diberlaku. Keselarasan itu dalam bentuk kedisiplinan para pegawai untuk mematuhi peraturan yang diberlakukan. Artinya para pegawai dalam bertindak maupun bersikap didalam organisasi memiliki tanggungjawab dan konsekuensi masing-masing yang akan menuntun untuk peningkatan kinerja pegawai. Pengaruh pimpinan dalam organisasi sangat penting. Kemampuan dalam memanajemen organisasi patut ditunjukkan dalam bentuk memotivasi bawahan. Agar mereka dapat secara tidak langsung memberikan feedback yang baik atas reward yang diberikan dalam bentuk peningkatan prduktivitas. Selain faktor dari eksternal berupa motivasi kerja, sikap mental pegawai yang bersedia dari diri sendiri untuk mengembangkan kemampuan kerjanya. Para pegawai selalu ingin mengembangkan kemampuan yang dimiliki agar berguna bagi organisasi. Hasil penelitian ini sesuai dengan penelitian yang pernah dilakukan oleh Putri Ayu Eka Ramadhani (2016). Terdapat pengaruh positif dan signifikan antara sikap mental terhadap kinerja ,Terdapat pengaruh positif dan signifikan motivasi keja terhadap kinerja dan terdapat pengaruh positif dan signifikan antara sikap mental dan motivasi kerja terhadap kinerja, sales marketing PT Inti Bharu Mas Lampung.

2. Pengaruh secara parsial kompetensi, disiplin kerja, sikap mental dan motivasi terhadap kinerja pegawai.

Hipotesis 2 dalam penelitian ini menyatakan bahwa kompetensi, disiplin kerja, sikap mental dan motivasi secara parsial berpengaruh signifikan terhadap kinerja pegawai. Berdasarkan hasil penelitian terdapat pengaruh signifikan 
antara kompetensi terhadap kinerja pegawai di Badan Kepegawaian dan Pengembangan Sumber Daya Manusia Kabupaten Barito Selatan, hal ini menunjukkan bahwa kompetensi mempunyai arti penting terhadap kinerja pegawai yang aktif bekerja di Badan Kepegawaian dan Pengembangan Sumber Daya Manusia Kabupaten Barito Selatan. Hasil penelitian ini searah dengan penelitian yang pernah dilakukan Fitriyadi (2001), hasil penelitian membuktikan bahwa Variabel Kompetensi Skill Teknis, kompetensi skill non teknis, knowledge dan ability mempunyai pengaruh yang signifikan terhadap peningkatan kinerja karyawan. Selanjutnya, hasil penelitian ini juga sejalan dengan hasil penelitian Astadi Pangarso dan Putri Intan Susanti (2016), yang menjelaskan bahwa variabel disiplin kerja mempunyai pengaruh yang signifikan terhadap peningkatan kinerja pegawai Biro Pelayanan Sosial Dasar Sekretariat Daerah Provinsi Jawa Barat. Hal ini ditunjukkan dengan beberapa uji yang dilakukan terhadap variabel disiplin kerja. Hasil penelitian menunjukkan bahwa dengan adanya disiplin kerja yang baik maka akan menghasilkan kinerja pegawai yang baik, sebaliknya apabila disiplin kerja kurang baik akan menghasilkan kinerja pegawai yang kurang baik pula. Hasil penelitian ini searah dengan pendapat Gibson (1997) dalam Umam (2018) menjelaskan sikap mental sebagai perasaan positif atau negatif atau keadaan mental yang selalu disiapkan, dipelajari dan diatur melalui pengalaman yang memberikan pengaruh khusus pada respons seseorang terhadap orang, obyek ataupun keadaan yang membawa pegawai kinerjanya. Hasil penelitian sesuai dengan penelitian yang pernah dilakukan oleh Putri Ayu Eka Ramadhani (2016) yang membuktikan bahwa : ada pengaruh positif dan signifikan antara sikap mental terhadap kinerja dan ada pengaruh positif dan signifikan antara sikap mental dan motivasi kerja terhadap kinerja sales marketing PT Inti Bharu Mas Lampung. Hasil penelitian ini juga sejalan dengan hasil penelitian yang pernah dilakukan oleh Deewar Mahesa (2010) yang menunjukkan bahwa Motivasi secara parsial berpengaruh terhadap Kinerja karyawan di PT Cocacola Amatil Indonesia Jawa Tengah

3. Kompetensi merupakan faktor yang paling dominan berpengaruh terhadap kinerja pegawai.

Hipotesis 3 dalam penelitian ini menyatakan bahwa kompetensi adalah faktor yang paling dominan berpengaruh terhadap kinerja pegawai dengan koefisien beta sebesar. Hasil dalam penelitian ini menunjukkan bahwa hipotesis 3 terbukti dan disimpulkan bahwa kompetensi merupakan faktor yang paling berpengaruh terhadap kinerja pegawai. Para pegawai Badan Kepegawaian dan Pengembangan Sumber Daya Manusia Kabupaten Barito Selatan menganggap dengan kompetensi yang dimiliki dengan maksimal akan menghasilkan kinerja yang optimal. Seorang pegawai yang memiliki kompetensi yang tinggi tentunya memiliki tingkat pengetahuan dan keterampilan yang tinggi pula. Oleh karena itu tanggungjawab pekerjaan yang dibebankan kepadanya akan dikerjakan dengan efektif dan efisien. Efektif dan efisien hasil pekerjaan yang diberikan dinilai dengan meningkatnya kinerja pegawai. Hasil penelitian ini sesuai dengan penelitian yang dilakukan oleh Oktriana Vertasari dan Zunaidah (2014) yang menyatakan bahwa variabel kompetensi berpengaruh paling dominan terhadap kinerja pegawai dibanding variabel lingkungan kerja dan kompensasi pada Badan Penanggulangan Bencana Daerah Sumatera Selatan. Hasil penelitian ini juga sejalan dengan penelitian A.Rahadi Iqzal Anshar, Abdul Rahman Mus dan Serlin Serang (2019) yang membuktikan bahwa variabel kompetensi lebih dominan berpengaruh terhadap kinerja pegawai dibandingkan 
variabel motivasi dan lingkungan kerja pada PT Datascrip Cabang Makassar.

\section{KESIMPULAN DAN SARAN}

1. Mengingat adanya pengaruh yang signifikan secara simultan dan parsial variabel kompetensi, disiplin kerja, sikap mental dan motivasi terhadap kinerja pegawai, disarankan kepada pihak yang berwenang mengambil keputusan, untuk mempertahankan atau bahkan meningkatkan kualitas Kompetensi, Disiplin Kerja, sikap mental dan motivasi kerja pada para pegawai agar kinerja pegawai tetap baik dan dapat memberikan kontribusi terhadap kinerja instansi tempat para pegawai bertugas.

2. Kompetensi berpengaruh dominan terhadap kinerja pegawai sehingga perlu menjadi perhatian khusus bagi BKPSDM Kabupaten Barito Selatan, karena hal ini menjadi tumpuan terhadap kinerja pegawai dan kinerja organisasi. Kompetensi pegawai perlu di-mantain secara terus menerus untuk menunjang tugas-tugas yang menjadi bebannya agar dapat terlaksana dengan baik melalui jenjang diklat, workshop, seminar dan pendidikan formal ke jenjang pendidikan yang lebih tinggi.

\section{DAFTAR PUSTAKA.}

Aswathappa K, 2002, Human Resource and Personnel Management Text and Cases, Third Edition, Tata McGrawHill Publishing Company Limited, New Delhi.

Bernardin, Russel, 1993. Human Resource Management, An Experiental Approach International, Edition, Mc Grow - Hill.

Boyatzis, RE, 1981, The Competence Manager : a Model for Effective Job Performance, New York, Wiley.

Gordon,J.R.1988.Organizational Behavior, a Diagnostic Aprroach. Fifth Edition. New York : Prentice Hall. McGraw Hill Book Compay.
Ghozali, Imam, 2001, Aplikasi Analisis

Multivariate Dengan Program SPSS, Edisi II, Penerbit Badan Penerbit Universitas Diponegoro, Semarang.

Handoko, T. Hani, 2000. Manajemen Personalia dan Sumber Daya Manusia. Yogyakarta : BPFE

Mulyasa, 2004, Kurikulum Berbasis Kompetensi; Konsep, Karakteristik dan Implementasi, Cetakan Keempat, Remaja Rosdakarya: Bandung.

Mathis, R.L. \& Jackson, J.H. 2000. Human Recources Management. New Jersey : Prentice Hall.

Spencer, Lyle M and Signe M, 1993. Competence of Work Communite of The American Bar Association and Communicate of Published. Printed in The United States of America.

Simamora Henry, 2004, Manajemen Sumber Daya Manusia, Edisi ketiga, Cetakana Pertama, STIE YKPN, Yogyakarta.

Soegiyono, 2007. Metode Penelitian Bisnis. Bandung : Alfabeta, CV.

Undang-Undang Republik Indonesia Nomor 8 Tahun 1974 Tentang Disiplin Pegawai Negeri Sipil. 